\title{
Aerobic exercise improves quality of life, psychological well-being and systemic inflammation in subjects with Alzheimer's disease.
}

\author{
Shehab M. Abd El-Kader', Osama H. Al-Jiffri ${ }^{2}$
}

1. Department of Physical Therapy, Faculty of Applied Medical Sciences, King Abdulaziz University, Jeddah, Saudi Arabia.

2. Department of Medical Laboratory Technology, Faculty of Applied Medical Sciences, King Abdulaziz University, Jeddah, Saudi Arabia.

\begin{abstract}
Background: Alzheimer's disease has a destructive drawbacks on the patient and his/her entire family as this disease badly affects the behavior, cognition and abilities to do activities of daily living (ADL). The physical and mental benefits of exercise are widely known but seldom available to persons suffering from Alzheimer's disease.

Objective: The aim of this study was to measure quality of life, systemic inflammation and psychological well-being response to aerobic exercises in Alzheimer's.

Methods: Forty Alzheimer elderly subjects were enrolled in two groups; the first group received treadmill aerobic exercise, while the second group was considered as a control group and received no training intervention for two months. Assessment of tumor necrosis factor-alpha (TNF- $\alpha$ ), interleukin-6 (IL-6), Rosenberg Self-Esteem Scale (RSES),Beck Depression Inventory (BDI), Profile of Mood States(POMS) and SF-36 health quality of life (SF-36 HRQL) were taken before and at the end of the study.

Results: There was a $25.2 \%, 19.4 \%, 23.5 \%, 21.3 \%, 17.7 \%, 11.7 \%, 12.5 \%$ and $10.1 \%$ reduction in mean values of $\mathrm{TNF}-\alpha$, IL-6, BDI, POMS, health transition SF-36 subscale, bodily pain SF-36 subscale, role functioning: emotional SF-36 subscale and mental health SF-36 subscale respectively in addition to $15.7 \%, 13.1 \%, 12.6 \%, 11.1 \%, 13.2 \%$ and $11.2 \%$ increase in mean values of RSES, physical functioning SF-36 subscale, role functioning:physical SF-36 subscale, general health SF-36 subscale, Vitality SF-36 subscale and Social functioning SF-36 subscale respectively in group (A) received aerobic exercise training, so that there was a significant reduction in the mean values of TNF- $\alpha$, IL-6, BDI \& POMS and increase in the mean values of SF-36 HRQL subscale scores, RSES in group (A) as a result of aerobic exercise training, while the results of group (B) who received no training intervention were not significant. Also, there were significant differences between mean levels of the investigated parameters in group (A) and group $(\mathrm{B})$ at the end of the study $(\mathrm{P}<0.05)$.

Conclusion: Treadmill walking exercise training is an effective treatment policy to improve quality of life, systemic inflammation and psychological wellbeing in Alzheimer's.
\end{abstract}

Keywords: Aerobic exercise, quality of life, psychological well-being, systemic inflammation, Alzheimer's.

DOI: http://dx.doi.org/10.4314/ahs.v16i4.22

Cite as: Abd El-Kader SM, Al-Jiffri OH. Aerobic exercise improves quality of life, psychological well-being and systemic inflammation in subjects with Alsheimer's disease. Afri Health Sci2016;16(4): 1045-1055. http://dx.doi.org/10.4314/abs.v16i4.22

\section{Introduction}

Alzheimer's disease is a slowly progressive neuropsychiatric disorder affecting mainly the brain regions of cognition and memory ${ }^{1}$. Globally, Alzheimer's disease affects about 27 million people of elderly population, however

\section{Corresponding author:}

Shehab M. Abd El-Kader,

Department of Physical Therapy,

Faculty of Applied Medical Sciences,

King Abdulaziz University,

P.O. Box 80324, Jeddah, 21589,Saudi Arabia.

E.mail: profshehab@live.com this number is expected to triple by $2050^{2}$. Although, aging is the major risk factor in Alzheimer's disease, genetics can be considered have a risk of Alzheimer's disease ${ }^{3}$. The cost of Alzheimer's disease management is high as it is about $\$ 183$ billion in United State of America, and is expected to be raised by $600 \%$ over the next 40 years ${ }^{4}$. Alzheimer's disease not only have a destructive drawbacks on the patient but on his entire family members as this disease badly affects the behavior, cognition and ability to do activities of daily living (ADL) ${ }^{5}$.

Several inflammatory mediators, including tumor necrosis factor-alpha (TNF- $\alpha$ ) and interleukin-6 (IL-6) are increased in Alzheimer's patients ${ }^{6}$. Several studies have 
established further the presence of inflammatory markers in the Alzheimer's disease brain ${ }^{7}$. CNS inflammation, impaired neuronal insulin signaling, and neuronal dysfunction in Alzheimer's disease may be a consequence of systemic inflammatory processes ${ }^{8,9}$. Neuro-inflammation plays an important role in Alzheimer's disease as well as in depression. Alzheimer's disease is often accompanied by symptoms of depression, anxiety, irritability, and mood instability ${ }^{10,11}$. Ultimately, this could contribute to or accelerate the onset of clinical manifestations of Alzheimer's disease ${ }^{12}$.

Psychiatric disturbances affect as many as $90 \%$ of patients with Alzheimer's disease and are a major focus of treatment. Depression is one of the most frequent psychiatric complications of Alzheimer's disease, affecting as many as $50 \%$ of patients ${ }^{13-15}$.

Aerobic exercise training is an effective and cost-efficient alternative therapy for disorders of anxiety and mood disorders ${ }^{16}$. Also, exercise training slows down the progression of cognitive decline ${ }^{17}$, improves performance on tests of cognition and psychological well-being ${ }^{18}$ and enhances sleep quality ${ }^{19}$. However, the available previous studies involving the impact of exercise training upon the quality of life, psychological wellbeing along with systemic inflammation in Alzheimer's disease is limited in number ${ }^{20}$.
Aerobic exercise training is hypothesized to improve cognition, physical performance, functional ability and quality of life. However, the available previous studies involving the impact of exercise training upon the quality of life, psychological well-being along with systemic inflammation in Alzheimer's disease are limited in number; so this study aimed to measure quality of life, systemic inflammation and psychological well-being response to aerobic exercises in Alzheimer's.

\section{Patients and methods}

Subjects

Forty elderly patients with Alzheimer's disease with age ranging from 65 to 75 years participated in this study. Exclusion criteria included smokers, subjects with pulmonary, cardiac, renal, hepatic, metabolic and neurological diseases. All the patients who participated in the study were non-smokers and continued on their ordinary diet throughout the study. Following pre-training testing, a randomized block procedure was used to assign qualified participants into two equal groups; group (A) received treadmill aerobic exercise, while the second group (B) was considered as a control group and received no training intervention for two months. The CONSORT diagram outlining the details of the screening, run-in and randomization phases of the study and reasons for participant exclusion figure (1). Informed consent was obtained from all participants. This study was approved by the Scientific Research Ethical Committee, Faculty of Applied Medical Sciences at King University. 


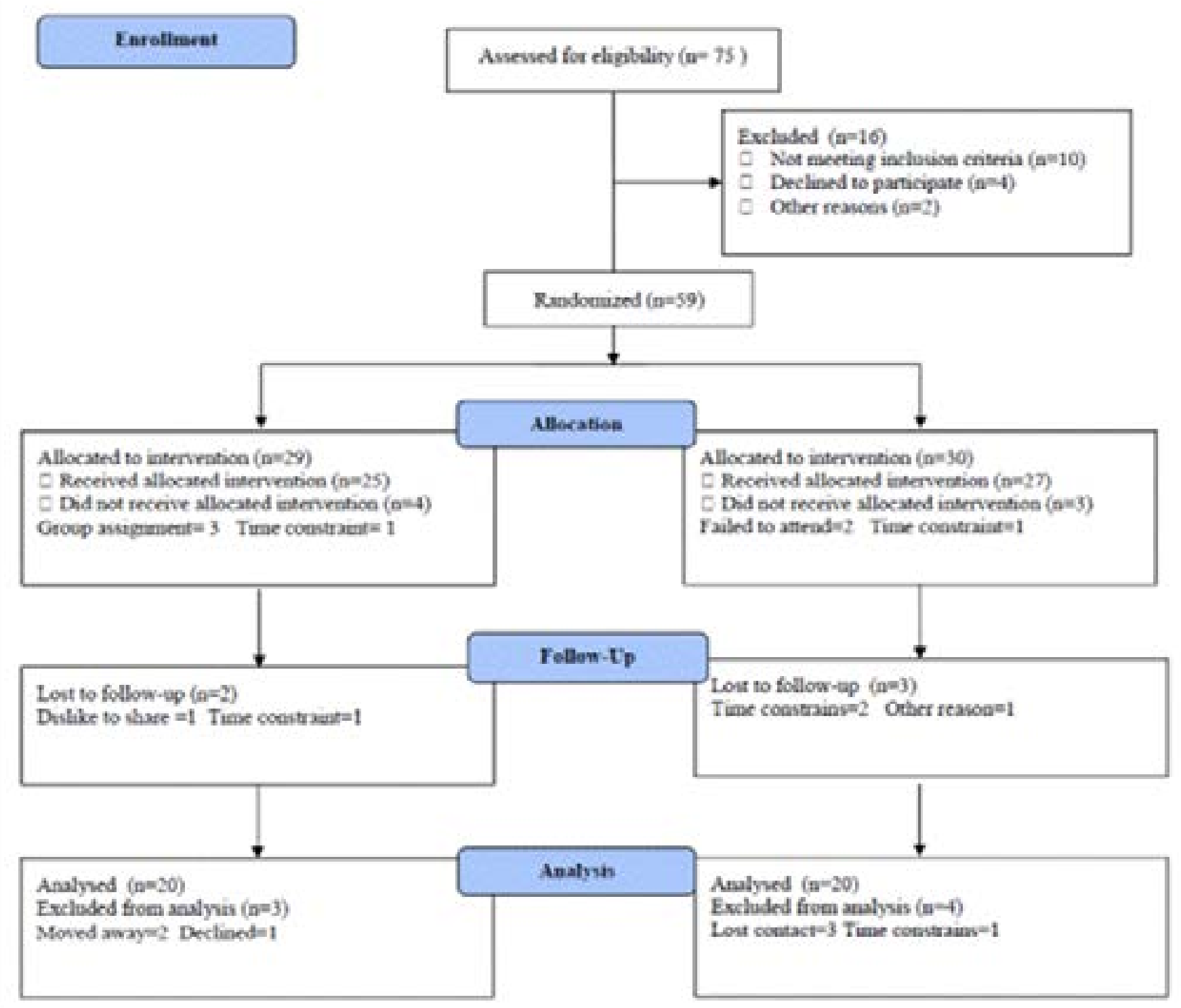

Figure (1) : Subjects screening and recruitment CONSORT diagram.

\section{Measurements}

1. Laboratory analysis: Blood samples were drained from the antecubital vein after a 12 -h fasting, the blood samples were centrifuged at $+4{ }^{\circ} \mathrm{C}(1000=\mathrm{g}$ for 10 min). Interleukin-6 (IL-6) level was analyzed by“'Immulite 2000" immunassay analyzer (Siemens Healthcare Diagnostics, Deerfield, USA). However, TNF- $\alpha$ level was measured by ELISA kits (ELX 50) in addition to ELISA microplate reader (ELX 808; BioTek Instruments, USA). All analyses were done by Hitachi 7170 Autoanalyser (Tokyo, Japan) and kits (Randox).
2. Psychological well-being: Assessment of psychological well-being included measurement of self-esteem and depression ${ }^{21}$. Self-esteem was evaluated using the Rosenberg Self-Esteem Scale (RSES) ${ }^{22}$, which included ten items to be answered on a four point Likert scale. Mood disturbance was measured by Profile of Mood States (POMS ${ }^{23}$; it assessed the transient emotional state by 65 items on a 5 -point Likert scale. This questionnaire evaluated 6 dimensions of mood in order to detect a Total Mood Disturbance score. However, depression was measured using the Beck Depression Inventory (BDI), a twenty-one item was covered to detect the total score for measuring the symptoms of depression ${ }^{24}$. 
3. Health-related quality of life (SF-36 HRQL): Health-related quality of life was assessed by SF-36 which includes eight subscales: vitality, bodily pain, general health, physical functioning, social functioning, physical Role Functioning, emotional role functioning, and mental health. The SF-36 was a questionnaire for detecting the amount of change in their general health over the past year ${ }^{25}$.

Measurements of TNF- $\alpha$, IL-6, RSES, BDI, POMS and SF-36 HRQL were done before the study (pre-test) and after the study (post-test).

\section{Procedures}

Following the previous evaluation, all participants were divided to the following groups:

1. Group (A) participated in treadmill aerobic exercise (Enraf Nonium, Model display panel Standard, NR 1475.801, Holand) which was conducted according to recommendation of aerobic exercise application for elderly approved by the American College of Sports Medicine and the National Institute on Aging ${ }^{26-27}$. Training program included 5 minutes for warming-up in the form of range motion and stretching exercises, 10-30 minutes of aerobic exercise training $(60-70 \%$ of maximum heart rate) and 10 minutes of cooling down ( on treadmill with low speed and without inclination). Participants had 3 sessions/week for 2 months with close supervision by physical therapist.

\section{Group (B) received no exercise training. Statistical analysis}

The mean values of the investigated parameters obtained before and after two months in both groups were compared using paired " $t$ " test. Independent " $t$ " test was used for the comparison between the two groups $(\mathrm{P}<0.05)$.

\section{Results}

Table (1) shows the baseline characteristics of the participants who entered the trial. However, there was a $25.2 \%, 19.4 \%, 23.5 \%, 21.3 \%, 17.7 \%, 11.7 \%, 12.5 \%$ and $10.1 \%$ reduction in mean values of TNF- $\alpha$, IL-6, BDI, POMS, health transition SF-36 subscale, bodily pain SF36 subscale, role functioning: emotional SF-36 subscale and mental health SF-36 subscale respectively in addition to $15.7 \%, 13.1 \%, 12.6 \%, 11.1 \%, 13.2 \%$ and $11.2 \%$ increase in mean values of RSES, physical functioning SF-36 subscale, role functioning: physical SF-36 subscale, general health SF-36 subscale, vitality SF-36 subscale and social functioning SF-36 subscale respectively in group (A) who received aerobic exercise training. There was a significant reduction in the mean values of TNF- $\alpha$, IL- 6 , BDI \& POMS and increase in the mean values of SF36 HRQLsubscale scores, RSES in group (A) as a result of aerobic exercise training(table 2), while the results of group (B) who received no training intervention were not significant(table 3). Also, there were significant differences between mean levels of the investigated parameters in group (A) and group (B) at the end of the study (table 4) $(\mathrm{P}<0.05)$.

\section{Table (1): Baseline characteristics of study participants.}

\begin{tabular}{|l|l|l|c|}
\hline Characteristic & Group (A) & Group (B) & Significance \\
\hline Age $($ years) & $68.94 \pm 5.76$ & $69.13 \pm 6.12$ & $\mathrm{P}>0.05$ \\
\hline Gende r $(\mathrm{male} /$ female) & \multicolumn{1}{|c|}{$14 / 6$} & $15 / 5$ & $\mathrm{P}>0.05$ \\
\hline Weight $(\mathrm{kg})$ & $67.72 \pm 4.91$ & $65.41 \pm 5.17$ & $\mathrm{P}>0.05$ \\
\hline Height $(\mathrm{m})$ & $1.65 \pm 0.14$ & $1.63 \pm 0.12$ & $\mathrm{P}>0.05$ \\
\hline BMI $\left(\mathrm{kg} / \mathrm{m}^{2}\right)$ & $23.57 \pm 3.65$ & $24.13 \pm 3.83$ & $\mathrm{P}>0.05$ \\
\hline SBP $(\mathrm{mmHg})$ & $138.65 \pm 12.11$ & $140.43 \pm 11.82$ & $\mathrm{P}>0.05$ \\
\hline DBP $(\mathrm{mmHg})$ & $83.23 \pm 9.42$ & $84.18 \pm 9.17$ & $\mathrm{P}>0.05$ \\
\hline
\end{tabular}

BMI: Body mass index; SBP: Sy stolic blood pressure; DBP: Diastolic blood pressure 
Table (2): Mean value and significance of TNF- $\alpha$, IL-6, RSES, BDI, POMS and SF-36 subscale scores in group (A) before and at the end of the study.

\begin{tabular}{|c|c|c|c|}
\hline & \multicolumn{2}{|c|}{ Mean \pm SD } & \multirow[t]{2}{*}{ Significance } \\
\hline & Before & After & \\
\hline TNF- $\boldsymbol{\alpha}(\mathrm{pg} / \mathrm{ml})$ & $4.87 \pm 1.65$ & $3.64 \pm 1.32 *$ & $\mathrm{P}<0.05$ \\
\hline IL-6 (pg/ml) & $2.63 \pm 0.84$ & $2.12 \pm 0.75 *$ & $\mathrm{P}<0.05$ \\
\hline RSES & $22.16 \pm 5.61$ & $25.65 \pm 6.24^{*}$ & $\mathrm{P}<0.05$ \\
\hline BDI & $8.01 \pm 2.72$ & $6.13 \pm 2.91 *$ & $\mathrm{P}<0.05$ \\
\hline POMS & $24.42 \pm 4.88$ & $19.21 \pm 4.37^{*}$ & $\mathrm{P}<0.05$ \\
\hline \multicolumn{4}{|l|}{ SF-36 subs cale variables } \\
\hline SF-36: Health transition & $2.93 \pm 0.71$ & $2.41 \pm 0.64 *$ & $\mathrm{P}<0.05$ \\
\hline SF-36: Physical functioning & 71.528 .64 & $80.847 .25^{*}$ & $\mathrm{P}<0.05$ \\
\hline SF-36: Role functioning: Physical & 81.839 .15 & $92.169 .82 *$ & $\mathrm{P}<0.05$ \\
\hline SF-36: Bodily pain & 75.167 .13 & $66.326 .55 *$ & $\mathrm{P}<0.05$ \\
\hline SF-36: General health & 71.438 .45 & $79.359 .11 *$ & $\mathrm{P}<0.05$ \\
\hline SF-36: Vitality & 54.976 .14 & $62.217 .82 *$ & $\mathrm{P}<0.05$ \\
\hline SF-36: Social functioning & $86.12 \pm 9.31$ & $95.83 \pm 10.04^{*}$ & $\mathrm{P}<0.05$ \\
\hline $\begin{array}{l}\text { SF-36: Role functioning: } \\
\text { Emotional }\end{array}$ & $92.18 \pm 10.18$ & $80.62 \pm 8.97 *$ & $\mathrm{P}<0.05$ \\
\hline SF-36: Mental health & $84.75 \pm 8.66$ & $76.15 \pm 7.52 *$ & $\mathrm{P}<0.05$ \\
\hline
\end{tabular}

\section{Table (3): Mean value and significance of TNF-a, I-6, RSES, BDI, POMS and SF-36 subscale sceres in gromp (B) before and at the end of the study.}

\begin{tabular}{|c|c|c|c|}
\hline & \multicolumn{2}{|c|}{ Mean tSD } & \multirow[t]{2}{*}{ Significance } \\
\hline & Before & After & \\
\hline INF-a (p/mI) & $4.62 \pm 1.48$ & $4.77 \pm 1.51$ & $P>0.05$ \\
\hline II,6 (pg/mi) & $2.54 \pm 0.96$ & $2.78 \pm 1.07$ & $P>0.05$ \\
\hline RSWS & $22.41 \pm 5.22$ & $22.25 \pm 5.18$ & $P>0.05$ \\
\hline BDI & $7.82 \pm 2.43$ & $7.96 \pm 2.61$ & $P>0.05$ \\
\hline POMS & $23.95 \pm 4.56$ & $24.28 \pm 4.73$ & $P>0.05$ \\
\hline \multicolumn{4}{|l|}{ SF-36 snbseale variables } \\
\hline SF-36:Healh transition & $2.71 \pm 0.65$ & $2.94 \pm 0.67$ & $P=0.05$ \\
\hline SF-36:Physical firnctioning & 72.167 .98 & 71.787 .65 & $P=0.05$ \\
\hline SF-36:Roke finctioning: Physical & 80.949 .53 & 80.659 .23 & $P=0.05$ \\
\hline SF-36:Bodlily pain & 74.136 .54 & 74.786 .38 & $\mathbf{P}>0.05$ \\
\hline SF-36: Gencral health & 72.218 .02 & 71.957 .87 & $P>0.05$ \\
\hline SF-36:Vitality & 55.366 .11 & 55.285 .94 & $P>0.05$ \\
\hline SF-36: Socinl finctioning & $87.28 \pm 7.93$ & $87.13 \pm 7.90$ & $P>0.05$ \\
\hline $\begin{array}{l}\text { SF-36:Role finctioning: } \\
\text { Emotional }\end{array}$ & $90.54 \pm 10.04$ & $91.12 \pm 9.86$ & $P>0.05$ \\
\hline SF-36:Mental heahh & $83.83+9.36$ & $84.17+9.51$ & $P>0.05$ \\
\hline
\end{tabular}

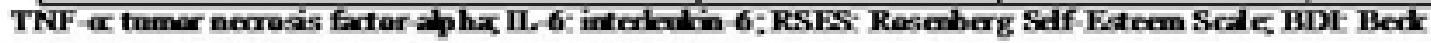
Depresion Imvertory. FOMS : Profile of Meod States. 


\section{Table (4): Mean value and significance of TNF- $\alpha$, IL-6, RSES, BDI, POMS and SF-36 subscale scores in group (A) and group (B) at the end of the study.}

\begin{tabular}{|l|c|c|c|}
\hline \multirow{2}{*}{ TNF- $\alpha(\mathrm{pg} / \mathrm{ml})$} & \multicolumn{2}{|c|}{ Mean +SD } & \multirow{2}{*}{ Significance } \\
\cline { 2 - 3 } & Group(A) & Group (B) & \\
\hline IL-6 $(\mathrm{pg} / \mathrm{ml})$ & $3.64 \pm 1.32^{*}$ & $4.77 \pm 1.51$ & $\mathrm{P}>0.05$ \\
\hline RSES & $2.12 \pm 0.75^{*}$ & $2.78 \pm 1.07$ & $\mathrm{P}>0.05$ \\
\hline BDI & $25.65 \pm 6.24^{*}$ & $22.25 \pm 5.18$ & $\mathrm{P}>0.05$ \\
\hline POMS & $6.13 \pm 2.91^{*}$ & $7.96 \pm 2.61$ & $\mathrm{P}>0.05$ \\
\hline SF-36 subscale variables & $19.21 \pm 4.37^{*}$ & $24.28 \pm 4.73$ & $\mathrm{P}>0.05$ \\
\hline SF-36: Health transition & $2.41 \pm 0.64^{*}$ & $2.94 \pm 0.67$ & $\mathrm{P}>0.05$ \\
\hline SF-36: Physical functioning & $80.847 .25^{*}$ & 71.787 .65 & $\mathrm{P}>0.05$ \\
\hline $\begin{array}{l}\text { SF-36: Role functioning: } \\
\text { Physical }\end{array}$ & $92.169 .82^{*}$ & 80.659 .23 & $\mathrm{P}>0.05$ \\
\hline SF-36: Bodily pain & $66.326 .55^{*}$ & 74.786 .38 & $\mathrm{P}>0.05$ \\
\hline SF-36: General health & $79.359 .11^{*}$ & 71.957 .87 & $\mathrm{P}>0.05$ \\
\hline SF-36: Vitality & $62.217 .82^{*}$ & 55.285 .94 & $\mathrm{P}>0.05$ \\
\hline SF-36: Social functioning & $95.83 \pm 10.04^{*}$ & $87.13 \pm 7.90$ & $\mathrm{P}>0.05$ \\
\hline $\begin{array}{l}\text { SF-36: Role functioning: } \\
\text { Emotional }\end{array}$ & $80.62 \pm 8.97^{*}$ & $91.12 \pm 9.86$ & $\mathrm{P}>0.05$ \\
\hline SF-36: Mental health & $76.15 \pm 7.52^{*}$ & $84.17+9.51$ & $\mathrm{P}>0.05$ \\
\hline
\end{tabular}

TNF- $\alpha$ : tumor necrosis factor-alpha; IL-6: interleukin-6; RSES: Rosenberg Self-Esteem Scale; BDI: Beck Depression Inventory; POMS: Profile of Mood States, $(*)$ indicates a significant difference between the two groups, $\mathrm{P}<0.05$.

\section{Discussion}

Despite the growing evidence on the benefits of exercise on the health and functioning of older adults with cognitive disorders, the available literature lacks clinical evidence that supports recommendations for exercise guidelines in people with Alzheimer's disease ${ }^{28}$. So, the aim of this study was to detect changes inquality of life, systemic inflammation and psychological wellbeing in response to aerobic exercise training inAlzheimer's. The results of the present study indicated that there was a significant reduction in mean values of Beck Depression Inventory (BDI) and Profile of Mood States(POMS) in response to aerobic exercise training in Alzheimer's. There is a growing body of evidence indicates that aerobic exercise is an effective and cost-efficient treatment alternative for a variety of anxiety and mood disorders, including panic disorder ${ }^{29}$. Craft found that a depressed group who undertook aerobic exercise for nine weeks had significantly higher coping efficacy than a non-exercise control ${ }^{30}$. In a sample of 101 healthy older adults randomized to four months of aerobic exercise, a yoga/flexibility control group, or wait list, assessment of scores from pre- to post-treatment revealed that depressive symptoms were reduced, especially in men ${ }^{31}$. Also, Blumenthal in his study on $156 \mathrm{com}-$ munity dwellers diagnosed with major depression who were randomized to supervised exercise, medication, or a combination of exercise and medication. The 16-week exercise treatment consisted of three weekly sessions of aerobic activity. By the end of the treatment period, each of the three treatment groups experienced a significant reduction in their levels of depression. The treatments did not differ significantly from one another in efficacy. These results suggest that exercise may be a viable alternative to medication in the treatment of depression in older adults ${ }^{32}$. However, Mota-Pereira et al. conducted a study a 12 week, home-based exercise program of 30$45 \mathrm{~min} /$ day walks, 5 days/week on 150 individuals with treatment-resistant major depression, results showed improved depression and functioning parameters and contributed to remission of $26 \%$ of these patients. Moderate 
intensity exercise may be a helpful and effective adjuvant therapy for treatment-resistant major depression ${ }^{33}$.

A number of potential mechanisms may be responsible for the reductions in depression associated with physical exercise e.g. physiological mechanisms hypothesized include the central monoamine theory (i.e., exercise corrects dysregulation of the central monoamines believed to lead to depression), as well as consideration of the role of the hypothalamic-pituitary-adrenal (HPA) axis (i.e., some depressed individuals exhibit HPA hyperactivity in response to stress and exercise may regulate this activity) $)^{34,35}$.

Our results revealed that serum IL- 6 and TNF- $\alpha$ were significantly decreased in response to aerobic exercise training in Alzheimer's. Our findings were consistent with Goldhammer et al. who found large (48\%; 7.5 to 3.9 $\mathrm{mg} / \mathrm{L})$ reductions in serum CRP in 28 elderly coronary heart disease patients in response to 12 weeks of aerobic exercise training as offered in typical Phase II cardiac rehabilitation programs ${ }^{36}$. In a study by Kohut et al. sedentary, low fit older adults aged $>64$ years were randomized to moderate aerobic exercise training $(65-80 \%$ heart rate reserve, 3 times per week, 30-45min/day) or flexibility control group for 10 months. Exercisers had a significant reduction in serum $C$ reactive protein (CRP), IL-6, interleukin-18 (IL-18) and TNF- $\alpha$ when compared to the flexibility group ${ }^{37}$. Also, Nicklas et al. examined the effects of 12 months of moderate walking training on plasma CRP and IL-6. Four hundred and twenty four sedentary, overweight/obese (BMI >28), community-dwelling elderly (70-89 years) were randomized to treatment. The exercise intervention resulted in a significant $16 \%$ reduction in IL6. CRP was $32 \%$ lower after exercise ${ }^{38}$. Moreover, Ogawa et al. found that 12 week of strength training significantly reduced serum CRP despite having no effect on body weight or waist circumference ${ }^{39}$.

The potential mechanisms of exercise training-induced reductions in inflammation in Alzheimer's disease patients include loss of adipose tissue which induced reductions in serum markers of inflammation ${ }^{40,41}$. Exercise training also increases vagal tone ${ }^{42}$, which according to the cholinergic anti-inflammatory reflex espoused by Tracy, could lead to reductions in systemic inflammation ${ }^{43}$. Acute exercise activates the hypothalamic-pituitary-adrenal axis and sympathetic nervous systems. Cortisol is known to have potent anti-inflammatory effects 44 and catecholamine can inhibit pro-inflammatory cytokine production ${ }^{45}$.Several studies have demonstrated that exercise training can down regulate toll-like receptor 4 , ligation of which activates pro-inflammatory cascades ${ }^{46,47}$.

Furthermore, on analyzing the quality of life changes in response aerobic exercise training in Alzheimer's, we found a significant improvement in the mean values of SF-36 subscale scores. Our findings were consistent with several studies have shown that exercise intervention might enhance health-related quality of life and psychological well-being ${ }^{48-50}$. Mahendra conducted a randomized controlled trial for 3 months follow-up, percentage of participants exercising $\geq 60 \mathrm{~min}$ per week increased in the exercise group compared with routine care. Exercise improved levels of physical functioning (SF-36 score) and depression compared with people in routine care (whose levels worsened). At 24 months, longitudinal analyses of all follow-up data revealed improvements in exercise group physical functioning (SF-36) and mobility compared with routine care ${ }^{51}$. Also, Schmitz et al. conducted the German National Health Interview and Examination Survey (GHS) on 7,124 persons, 18-79 years of age. Results revealed that higher levels of physical activity were associated with higher health-related quality of life among persons with mental disorders and physically inactive subjects reported poorer quality of life ${ }^{52}$. Bowen et al. proved that 12-month exercise intervention (225 min/week) improved physical functioning and general health scores among sedentary postmenopausal women (vs. controls) $)^{53}$. Improved HRQOL was also noted in another 12-month exercise trial (60 min/day, 3 times/ week) among middle-aged adults ${ }^{54}$. While, Imayama et al. conducted a study one middle-aged women $(n=100)$ and $\operatorname{men}(\mathrm{n}=102)$ who were randomly assigned to either exercise (360 $\mathrm{min} /$ week of moderate-to-vigorous aerobic exercise) or control and HRQOL (SF-36)were assessed at baseline and 12 months and proved that this level of exercise may increase HRQOL among overweight men ${ }^{55}$. Similarly, a survey of European adults found that being physically active ( $\geq 24$ MET-h/week) is associated with better mental health compared with being less active $(\leq 24$ MET-h/week $)^{56,57}$. Moreover, Hoffmann etal. conducted a study of exercise sessions in a group of 3-5 participants for 1 hour, 3 times per week for 16 weeks. The purpose 
of the first 4 weeks of exercise is to accustom the participants to exercising (adaptation exercise). During the next 12 weeks, the exercise is designed to achieve an intensity of $70-80 \%$ of heart rate reserve. Results proved that moderate intensity aerobic could improve cognition, quality of life, physical health and functional ability in patients with Alzheimer's disease ${ }^{58}$.

Although the exact mechanism for the effect of exercises on mental health is still unknown, several physiological and psychological mechanisms have been proposed, including increased feelings of self-efficacy, self-perceptions of control, reduced emotional strain and physiological responses to stress, and beneficial effects on neurotransmitters $^{59}$. Also, physical activity may have a trophic effect on the brain, particularly the hippo-campus. For instance, exercise increases brain-derived neurotrophic factor $(B D N F)^{60}$. Exercise appears to stimulate neurogenesis ${ }^{61}$, enhance neuronal survival ${ }^{62}$, increase resistance to brain insults $^{63,64}$ and increase synaptic plasticity ${ }^{65}$. Exercise promotes brain vascularization ${ }^{66,67}$, mobilizes gene expression profiles predicted to benefit brain plasticity ${ }^{68}$. Social contact may be an important mechanism, and subjects who take regular exercise may, as a result, get positive feedback from other people and an increased sense of self-worth ${ }^{69}$.

The current study has important strengths and limitations. The major strength is the supervised nature of the study. Supervising physical activity removes the need to question compliance or to rely on activity questionnaires. Furthermore, all exercise sessions were supervised and adherence to the activities was essentially 100\%. Moreover, the study was randomized; hence, we can extrapolate adherence to the general population. On the other hand, the major limitations is only Alzheimer's patients were enrolled in the study, so the value of this study is only related to Alzheimer's in this age group, also the small sample size in both groups may limit the possibility of generalization of the findings in the present study, in addition, a number of confounders such as socioeconomic indicators like education level, previous occupation and income which should be controlled as they can affect the outcomes were not measured. Finally, within the limit of this study, aerobic exercise training is recommended for modulation of low grade systemic inflammation and poor quality of life among Alzheimer's. Further researches are needed to explore the impact of different therapeutic interventions on quality of life and other biochemical parameters among Alzheimer's.

\section{Conclusion}

The current study provides evidence that treadmill walking exercise training is an effective treatment policy to improve quality of life, systemic inflammation and psychological wellbeing in Alzheimer's.

\section{Acknowledgment}

This project was funded by the Deanship of Scientific Research (DSR), King Abdulaziz University, Jeddah, under grant no. (34-142-1437-G). The authors, therefore, acknowledge with thanks DSR technical and financial support.

\section{References}

1. Müller UC, Zheng $H$. Physiological functions of APP family proteins. Cold Spring Harb Perspect Med 2012;2(2):a006288.

2. Rubio-Perez JM and Morillas-Ruiz JM. A review: inflammatory process in Alzheimer's disease, role of cytokines. Scientific World Journal 2012; 2012: 756357.

3. Candore G, Balistreri CR, Colonna-Romano G, Lio D, Listì F, Vasto S, Caruso C. Gender-related immuneinflammatory factors, age-related diseases, and longevity. Rejuvenation Res 2010;13:292-297. PubMed

4. Thies W, Bleiler L. Alzheimer's disease facts and figures. Alzheimers Dement 2011; 7:208-44 PubMed

5. Melrose R J, Ettenhofer ML, Harwood D, Achamallah N, Campa O, Mandelkern M. Cerebral metabolism, cognition and functional abilities in Alzheimer disease. Journal of Geriatric Psychiatry and Neurology 2011; 24:127-134.

6. Lee CY, Landreth GE. The role of microglia in amyloid clearance from the AD brain. J Neural Transm 2010; 117:949-60. PubMed

7. Swardfager W, Lanctot K, Rothenburg L, Wong A, Cappell J, Herrmann N. A meta-analysis of cytokines in Alzheimer's disease. Biol Psychiatry 2010; 68:930-41. PubMed

8. De Felice FG. Alzheimer's disease and insulin resistance: translating basic science into clinical applications. $J$ Clin Invest 2013;123:531-9.

9. Mattson MP. Energy intake and exercise as determinants of brain health and vulnerability to injury and disease. Cell Metab 2012; 16:706-22. PubMed

10. Dobos N, Korf J, Luiten P, Eisel U. Neuroinflamma- 
tion in Alzheimer's disease and Major Depression .BIOL PSYCHIATRY 2010; 67:503-504. PubMed

11. Diniz BS, Teixeira AL, Ojopi EB, Talib LL, Mendonça VA, Gattaz WF, Forlenza OV. Higher serum sTNFR1 level predicts conversion from mild cognitive impairment to Alzheimer's disease. J Alzhbeimers Dis 2010; 22:1305-1311 PubMed

12. Ferreira ST, Clarke JR, Bomfim TR, De Felice FG. Inflammation, defective insulin signaling, and neuronal dysfunction in Alzheimer's disease. Alzheimers Dement 2014;10(1 Suppl):S76-83. PubMed

13. Mossaheb N, Zehetmayer S, Jungwirth S, Weissgram S, Rainer M, Tragl KH, Fischer P. Are specific symptoms of depression predictive of Alzheimer's dementia? J Clin Psychiatry 2012;73(7):1009-15. PubMed

14. Lyketsos CG, Carrillo MC, Ryan JM, Khachaturian AS, Trzepacz P, Amatniek J, Cedarbaum J, Brashear R, Miller DS. Neuropsychiatric symptoms in Alzheimer's disease. Alz̧beimers Dement 2011; 7(5):532-9. PubMed 15. Heun R, Schoepf D, Potluri R, Natalwala A. Alzheimer's disease and co-morbidity: increased prevalence and possible risk factors of excess mortality in a naturalistic 7-year follow-up. Eur Psychiatry 2013; 28(1):40-8. PubMed

16. Salmon P. Effects of physical exercise on anxiety, depression, and sensitivity to stress: a unifying theory. Clinical Psychology Review 2001; 21: 33-61.

17. Larson EB. Prospects for delaying the rising tide of worldwide, late-life dementias. International Psychogeriatrics 2010; 22:1196-1202.

18. Vogt T, Schneider S, Bruumer V, Struder H K. Frontal EEG asymmetry: The effects of sustained walking in the elderly. Neuroscience Letters 2010; 485:134-137.

19. Benloucif S, Orbeta L, Ortiz R, Janssen I, Finkel SI, Bleiberg J. Morning or evening activity improves neuropsychological performance and subjective sleep quality in older adults. Sleep 2004;15: 1542-1551. PubMed

20. van Gelder BM, Tijhuis MA, Kalmijn S, Giampaoli S, Nissinen A, Kromhout D. Physical activity in relation to cognitive decline in elderly men: The FINE study. Neurology 2004; 28: 2316-2321. PubMed

21. Palmeira A, Branco T, Martins S, Minderico C, Silva M, Vieira P. Change in body image and psychological well-being during behavioral obesity treatment: Associations with weight loss and maintenance. Body Image 2010; 7(3):187-193. PubMed

22. Rosenberg M. Society and the adolescent self-image. Princeton, NJ: Princeton University Press 1965.
23. McNair DM, Lorr N, Droppleman LF. Manual for the Profile of Mood States. San Diego: EdITS 1971.

24. Beck AT, Steer RA. Manual for the Beck depression inventory. New York:Psychological Corporation 1987.

25. Ware J, Kosinski M, Gandek B. SF-36 health survey: manual \& interpretation guide. Lincon, RI: Quality Metric Incorporated, 2000.

26. American College of Sports Medicine .Guidelinesfor graded exercise testing and exercise prescription, Lea \& Febiger, Philadelphia, 2005.

27. National Institute on Aging. Exercise a guide from the National Institute on Aging (NIH Publication no. 014258), U.S. Govermental Printing Office, Washington, DC 2004.

28. Heyn P, Abreu B, Ottenbacher K. The effects of exercise training on elderly people with cognitive impairment and dementia: a meta-analysis. Arch Phys Med Rehabil 2004; 85:1694-704.

29. Salmon P. Effects of physical exercise on anxiety, depression, and sensitivity to stress: a unifying theory. Clinical Psychology Review 2001;21:33-61.

30. Craft L. Exercise and clinical depression: examining two psychological mechanisms. Psychology in Sport and Exercise 2005;6:151-171.

31. Blumenthal JA, Emery CF, Madden DJ, George LK, Coleman RE, Riddle MW, McKee DC, Reasoner J, Williams RS. Cardiovascular and behavioral effects of aerobic exercise training in healthy older men and women. $J$ Gerontol A Biol Sci Med Sci 1989; 44:M147-57.

32. Blumenthal JA, Babyak MA, Moore KA, Craighead WE, Herman S, Khatri P, Waugh R, Napolitano MA, Forman LM, Appelbaum M, Doraiswamy PM, Krishnan KR. Effects of exercise training on older adults with major depression. Arch Intern Med 1999; 159:2349-56. PubMed 33. Mota-Pereira J, Silverio J, Carvalho S, Ribeiro JC, Fonte $\mathrm{D}$, Ramos J. Moderate exercise improves depression parameters in treatment-resistant patients with major depressive disorder. J Psychiatr Res 2011; 45(8):1005-11. PubMed

34. Brosse AL, Sheets ES, Lett HS, Blumenthal JA. Exercise and the treatment of clinical depression in adults: recent findings and future directions. Sports Med 2002; 32:741-60. PubMed

35. Barbour KA, Blumenthal JA. Exercise training and depression in older adults. Neurobiol Aging. 2005;26 Suppl 1:119-23.

36. Goldhammer E, Tanchilevitch A, Maor I, Beniamini Y, Rosenschein U, Sagiv M . Exercise training modulates

African Health Sciences Vol 16 Issue 4, December, 2016 
cytokines activity in coronary heart disease patients. Int J Cardiol 2005;100: 93-99 PubMed.

37. Kohut ML, McCann DA, Russell DW, Konopka DN, Cunnick JE, Franke WD, Castillo MC, Reighard AE, Vanderah E. Aerobic exercise, but not flexibility/resistance exercise, reduces serum IL-18, CRP, and IL-6 independent of beta-blockers, BMI, and psychosocial factors in older adults. Brain Behav Immun 2006;20: 201-209 PubMed 38. Nicklas BJ, Hsu F-C, Brinkley TJ, Church T, Goodpaster BH, Kritchevsky SB, Pahor M. Exercise training and plasma C-reactive protein and interleukin-6 in elderly people. Journal of the American Geriatrics Society 2008;56: 2045-2052.

39. Ogawa K, Sanada K, Machida S, Okutsu M, Suzuki K. Resistance exercise training-induced muscle hypertrophy was associated with reduction of inflammatory markers in elderly women. Mediators Inflamm 2010;2010:171023.

40. Fried SK, Bunkin DA, Greenberg AS. Omental and subcutaneous adipose tissues of obese subjects release interleukin-6: depot difference and regulation by glucocorticoid. J Clin Endocrinol Metab 1998;83: 847-850.

41. Harkins JM, Moustaid-Moussa N, Chung YJ, Penner KM, Pestka JJ, North CM, Claycombe KJ.Expression of interleukin- 6 is greater in preadipocytes than in adipocytes of 3T3-L1 cells and C57BL/6J and ob/ob mice. J Nutr 2004;134:2673-2677. PubMed

42. Routledge FS, Campbell TS, McFetridge-Durdle JA, Bacon SL. Improvements in heart rate variability with exercise therapy. The Canadian journal of cardiology 2010;26: 303-312.

43. Tracey KJ. Reflex control of immunity. Nat Rev Immunol 2009; 9: 418-428 PubMed .

44. Harbuz MS, Chover-Gonzalez AJ, Jessop DS. Hypothalamo-pituitary-adrenal axis and chronic immune activation. Annals of the New York Academy of Sciences 2003; 992: 99-106

45. Ignatowski TA, Gallant S, Spengler RN. Temporal regulation by adrenergic receptor stimulation of macrophage (M phi)-derived tumor necrosis factor (TNF) production post-LPS challenge. Journal of neuroimmunology 1996; 65: 107-117.

46. Flynn MG, McFarlin BK. Toll-like receptor 4: link to the anti-inflammatory effects of exercise?. Exercise and sport sciences reviews 2006;34: 176-181.

47. Takeda K, Kaisho T, Akira S. Toll-like receptors. Annual review of immunology 2003;21: 335-376.

48. Brown DW, Balluz LS, Heath GW. Associations between recommended levels of physical activity and health-related quality of life-Findings from the 2001 Behavioral Risk Factor Surveillance System (BRFSS) Survey. Prev Med 2003; 37:520-8. PubMed

49. Segal R, Evans W, Johnson D. Structured exercise improves physical functioning in women with stages I and II breast cancer: results of a randomized controlled trial. J Clin Oncol 2001; 19:657-65. PubMed

50. Painter P, Carlson L, Carey S, Paul SM, Myll J. Physical functioning and health-related quality-of-life changes with exercise training in hemodialysis patients. Am J Kidney Dis 2000; 35:482-92. PubMed

51. Mahendra N. Exercise and behavioural management training improves physical health and reduces depression in people with Alzheimer's disease. Evidence-based Healthcare 2004; 8: 77-79. PubMed

52. Schmitz N, Kruse J, Kugler J. The association between physical exercises and health-related quality of life in subjects with mental disorders: results from a cross-sectional survey. Preventive Medicine 2004;39:1200-1207. PubMed 53. Bowen DJ, Fesinmeyer MD, Yasui Y, Tworoger S, U1rich CM, Irwin ML, Rudolph RE, LaCroix KL, Schwartz RR, McTiernan A. Randomized trial of exercise in sedentary middle aged women: effects on quality of life. International Journal of Behavioral Nutrition and Physical Activity 2006, 3:34.

54. Sørensen M, Anderssen S, Hjerman I, Holme I, Ur$\sin \mathrm{H}$. The effect of exercise and diet on mental health and quality of life in middle-aged individuals with elevated risk factors for cardiovascular disease. J Sports Sci. 1999;17(5):369-77.

55. Imayama I, Alfano CM, Cadmus Bertram LA, Wang C, Xiao L, Duggan C, Campbell KL, Foster-Schubert KE, McTiernan A. Effects of 12-month exercise on healthrelated quality of life: a randomized controlled trial. Prev Med 2011; 52(5):344 -51. PubMed

56. Abu-Omar K, Rütten A, Lehtinen V. Mental health and physical activity in the European Union. Soz Praventivmed 2004;49(5):301-9:198-207. PubMed

59. Paluska SA, Schwenk TL. Physical activity and mental health: current concepts. Sports Med 2000; 29:167-80. PubMed

60. Nichol K, Deeny SP, Seif J, Camaclang K, Cotman CW. Exercise improves cognition and hippocampal plasticity in APOE epsilon4 mice. Alz̧heimers Dement 2009; 5:287-94. PubMed

61. van Praag H, Christie BR, Sejnowski TJ, Gage FH. 
Running enhances neurogenesis, learning, and long-term potentiation in mice. Proc Natl Acad Sci U S A 1999; 96:13427-31.

62. Barde YA. Neurotrophins: a family of proteins supporting the survival of neurons. Prog Clin Biol Res 1994; 390:45-56. PubMed

63. Stummer W, Weber K, Tranmer B, Baethmann A, Kempski O. Reduced mortality and brain damage after locomotor activity in gerbil forebrain ischemia. Stroke 1994; 25:1862-9. PubMed

64. Carro E, Trejo JL, Busiguina S, Torres-Aleman I. Circulating insulin-like growth factor I mediates the protective effects of physical exercise against brain insults of different etiology and anatomy. J Neurosci 2001; 21:567884. PubMed

65. Lu B, Chow A. Neurotrophins and hippocampal synaptic transmission and plasticity. J Neurosci Res 1999; 58:76-87. PubMed.

66. Black JE, Isaacs KR, Anderson BJ, Alcantara AA, Greenough WT. Learning causes synaptogenesis, whereas motor activity causes angiogenesis, in cerebellar cortex of adult rats. Proc Natl Acad Sci USA 1990; 87:5568-72.

67. Isaacs KR, Anderson BJ, Alcantara AA, Black JE, Greenough WT. Exercise and the brain: angiogenesis in the adult rat cerebellum after vigorous physical activity and motor skill learning. J Cereb Blood Flow Metab 1992; 12:110-9.

68. Cotman CW, Berchtold NC. Exercise: a behavioral intervention to enhance brain health and plasticity. Trends Neurosci 2002; 25:295-301. PubMed

69. Greist JH, Klein MH, Eischens RJ, Faris J, Gurman AS, Morgan WE. Running as treatment for depression. Compr Psycbiatry 1979; 20:41-54. PubMed 